\title{
Husbandry and Sustainability of Water Buffaloes in Turkey
}

\section{Orhan Ermetin*}

Department of Animal Science, Faculty of Agriculture Bozok University, 66900 Yozgat, Turkey

\section{A R T ICLE INFO}

${ }^{\#}$ The 4th International Conference on Sustainable Agriculture and Environment, Surakarta, Indonesa, August 10-12th 2017.

\section{Review Article}

Received 11 October 2017

Accepted 22 November 2017

\section{Keywords:}

Water buffalo

Anatolian water buffalo

Breeding

Production

Turkey

*Corresponding Author:

E-mail: orhan.ermetin@bozok.edu.tr

\begin{abstract}
A B S T R A C T
Water buffaloes in Turkey originate from Mediterranean Water Buffaloes, a subgroup of river water buffaloes and are known as Anatolian Water Buffalo. During the 1970's the number of water buffaloes in Turkey was one million, but in 2010 this figure dropped to about 85.000. Thanks to the incentives introduced for water buffalo husbandry in recent years, the water buffalo population has risen to 143.073 heads. Water buffalo husbandry in Turkey is performed in some provinces of the Black Sea, Marmara and Central Anatolian Regions. The provinces with the highest amount of water buffalo existence are listed as Samsun, Diyarbakır, Istanbul, Tokat, Bitlis, Muş, Afyon, Kayseri, Sivas and Amasya. Breeding style in Turkey is in the form small family business, with an average of 1-5 animals per enterprise. Family enterprises are keeping water buffaloes for their own consumption. Mostly breeding in modern enterprises formed for indoor barn breeding, the size of the herds is around 50 to 100 heads. Being done only at swamps or waterfronts in the past, water buffalo husbandry increasingly takes place in modern facilities nowadays. The colour of Anatolian Water Buffaloes is generally black and their horns curved backwards, are called arch horns in Turkey. The lactation milk yield and lactation length in Anatolian Water Buffaloes are between 800 and $1100 \mathrm{~kg}$ and about 180-280 days respectively. It is demonstrated that they varied according to effects of environmental factors, care and feeding. Adult water buffalo's live weight is about 411$518 \mathrm{~kg}$. The first insemination age of water buffalo is 32 to 43 months and during a lifespan the number of lactation periods is 5 to 10 . For adult water buffalo at withers the height of females is being expressed as around $135 \mathrm{~cm}$. Calves are generally breastfed for 3-4 months. Generally, water buffaloes are milked twice a day in the village farms by hand.
\end{abstract}

Türk Tarım - Gıda Bilim ve Teknoloji Dergisi, 5(12): 1673-1682, 2017

Türkiye'de Manda Yetiştiriciliği ve Sürdürülebilirliği

\section{A K A L E B İ L G İ S İ}

\section{Derleme Makale}

Geliş 11 Ekim 2017

Kabul 22 Kasım 2017

Anahtar Kelimeler:

Manda

Anadolu mandas1

Yetiştiricilik

Verim

Türkiye

Sorumlu Yazar:

E-mail: orhan.ermetin@ bozok.edu.tr

\section{Ö Z E T}

Türkiye'deki mandalar, nehir mandalarının alt grubu olan Akdeniz mandalarından köken almakta ve Anadolu mandası olarak adlandırılmaktadır. Türkiye' de 1980 yıllarda bir milyon manda varlığı varken, 2007 yılında 85.000 bine kadar düşmüştür. Son yıllarda manda yetiştiriciliğinde teşviklerin uygulanmasıyla birlikte manda varlığı 143.073 baş olmuştur. Türkiye'de manda yetiştiriciliği; Karadeniz, Marmara ve İç Anadolu bölgelerinde yoğun olarak yapılmaktadır. En çok manda sayısına sahip iller Samsun, Diyarbakır, İstanbul, Tokat, Bitlis, Muş, Afyon, Kayseri, Sivas ve Amasya olarak sıralanmaktadır. Yaygın yetiştirme biçimi küçük aile işletmeleri şeklinde, aile tüketimi için ve ortalama 1-5 başlıktır. Kapalı ahır besisi için oluşturulan sürülerde 50-100 başlık büyüklüğe ulaşılır. Geçmişte sadece bataklık veya su kenarlarında yapılan manda yetiştiriciliği günümüzde modern işletmelerde de yapılmaktadır. Türkiye'de mandalarının genel olarak rengi siyah olup, yay boynuz denilen geriye kavisli biçimde boynuzludur. Anadolu Mandalarının çevre şartları ve bakım beslemeye göre değişmekle birlikte laktasyon süt miktarları 800-1100 kg, laktasyon uzunluğu da 180-280 gün arasında değişiklik göstermektedir. Yetişkin manda ağırlıkları 411-518 kg arasındadır. Mandaların ilk malaklama yaşı 32-43 ay arası olup, bir manda için toplam ömürde 5-10 laktasyon dönemi söz konusudur. Ergin dişi mandalarda cidago yüksekliği yaklaşık $135 \mathrm{~cm}$ olarak ifade edilmektedir. Malaklar annelerini genelde 3-4 ay emmektedirler. Köy şartlarında sağım genellikle elle ve günde iki defa yapmaktadırlar. 


\section{Introduction}

Water buffalo is bred for meat and milk, its skin, horn and manure are made use of and in some countries and enterprises, it is also being used as a draught animal. Even though water buffalo was not valued as highly as other livestock until this day, it has become more regarded both in Turkey and in various other countries, due to its numerous characteristics and yield. Particularly in countries with suitable conditions, water buffalo breeding is starting to get the attention it deserves. Among the characteristics that is making water buffalo important are; durability against nature and diseases, high level of capacity to make good use of fodder, the capacity of converting low-quality roughage into meat and milk, lower breeding costs than cattle and austerity when it comes to feeding (Atasever and Erdem, 2008). Water buffalo rumen is developing earlier than that of cattle and is richer in terms of rumen bacteria, which makes it able to make use of roughage, unlike other animals (Guyton, 1991). Being also highly suitable for pasture raising makes water buffalo an economic milk and working animal for small agricultural enterprises. Contaminated with diseases, meadows are not suitable for cattle, sheep and pigs, but water buffalo makes the most use of them, without any dangers (Sarıözkan, 2011). Being particularly resistant to diseases such as piroplasmosis, distomatosis and anoplasmosis is one of the advantages of water buffalo. Water buffalo is generally an animal of humid, temperate and marshy regions, thus it cannot adapt well to extremely warm or cold temperatures. In regions with suitable environmental conditions, it can be more economic than cattle (Harvey, 1963). A great ability to adapt to the environment and various conditions, water buffalo is found to wallow in mud (Fisher, 1975). Most of the domestic water buffaloes in the world $(95 \%)$ are found in the Far East. As a meat, milk and draught animal, water buffalo has a particularly great economic efficiency in the tropical and subtropical regions of Asia. In addition, it is also bred in South American countries, North Africa, all Mediterranean countries excluding France, Balkans and some Central European countries Australia. Their numbers in the southern hemisphere are low.

Having over 70 different species under domestic and wild categories, domestic water buffaloes are divided into two groups, "River (Stream) Buffalo" and "Swamp Buffalo". River buffalo with Indian origin is a race with a combined efficiency, mostly bred for meat and milk. Swamp buffalo, known as "Carabao", on the other hand is not suitable for milk production and is a race found in China and South-East Asia and used for milk and meat production as well as ploughing fields (Atasever and Erdem, 2008). Water buffaloes in Turkey originate from Mediterranean Water Buffaloes, a subgroup of river water buffaloes and are known as Anatolian Water Buffalo (Soysal et al., 2005).

\section{Water Buffalo Husbandry and Its Importance}

Water buffalo is a late developer when compared to cattle, and the development continues until the age of six. Its lifespan is about 30 years. It reaches the age of sexual maturity later than cattle. Water buffalo heifers reach sexual maturity when 13-14 months old. Therefore, water buffalo heifers can be inseminatedwhen 22 - 24 months old. While male water buffaloes can be used as bulls after the age of 20-21 months. Male water buffaloes can be used as a bully until they reach 5-6. The breeder age of bulls is about 2-15 years (Anonymus, 2003).

Rutting in water buffalo cows is not as distinct as in cattle and its rutting period is calmer. Pregnancy periods of water buffaloes range between 299 - 346 days, depending on race, climate and country of breeding, but onaverage, this duration is 315 - 319 days. Birth lasts five hours on average and it takes place mostly during the quiet hours of the day, at night time or early morning, and usually no help is needed. Water buffaloes usually birth a single calf (Anonymus, 2003).

Adult skin thickness in water buffaloes is $6.0-7.6 \mathrm{~mm}$, and thicker than cattle skin. However, the hair cover and subcutaneous sweat glands are 1/10 times less than those found in the cattle skin. Due to shortage of sweat glands and hair cover, it cannot self-regulate its body heat during warm summer months, becomes uncomfortable; hence feels the need to swim in the water or wallow in marsh or mud. In addition, due to low skin, hair density, resistance against cold weather is lower than that of cattle (Şahin and Küçükkebabçı, 2002).

Particularly in low-income countries, water buffaloes are important to farm animals in economic terms, and they are used for milk, meat, skin and drought. Milk yield in water buffaloes is 1850-2000 liters on average. The food substance content of water buffalo milk is higher than that of cow's milk. Water buffalo milk contains more calories than cow's milk, and as the total dry matter is higher, it increases the yield of dairy products such as cream, butter and cheese. While cow's milk yields 70 calories per 100 grams, water buffalo milk yields 100 calories. Having greater fat globules, high levels of solid fat, makes it easier to churn butter and to separate cream. Fat percentage taken from water buffalo milk is noticeably higher than that taken from cow milk (ElSalam and El-Shibiny, 2011). When compared to cow milk, water buffalo milk has lower cholesterol levels and higher tocopherol levels. Water buffalo milk, with its white color, high-fat content and taste, are milk preferred by consumers. Water buffalo milk can be stored for longer, as it has a higher peroxidase activity. When compared to cow milk, it has higher calcium content, better calcium/phosphor ratio, and lower sodium and potassium levels, which make it a better nutritional supplement for newborns. Comparing water buffalo milk with a cow, sheep and goat milk reveals that it is superior in many terms (Küçükkebapçı and Şahin, 2002; Wanapat and SungChhang, 2013; Aköz et al., 2017). Due to their adapting capacities, ability to make use of low-quality fodder, and having fats with lower cholesterol and higher unsaturated fat acids in their meat and milk, water buffaloes are irreplaceable in terms of genetic biodiversity (Borghese, 2010).

Comparison of water buffalo milk's composition with milk taken from other farm animals has been given in Table 1. 
Table 1 Comparing the composition of water buffalo milk with milk content of some other farm animals (\%)*

\begin{tabular}{l|rrrrrr}
\multicolumn{1}{c|}{ Kind of Milk } & Water & Dry matter & Protein & Fat & Lactose & Mineral matter \\
\hline Water buffalo & 82.0 & 17.7 & 4.2 & 7.85 & 4.80 & 0.77 \\
Cattle & 87.5 & 12.4 & 3.4 & 3.65 & 4.65 & 0.75 \\
Sheep & 82.9 & 17.2 & 5.4 & 6.25 & 4.55 & 0.88 \\
Goat & 87.1 & 13.0 & 3.7 & 4.10 & 4.45 & 0.80 \\
\hline
\end{tabular}

*(Oysun, 1987; Demirci et al., 1991; Atasever and Erdem, 2008)

Table 2 Comparing beef and water buffalo meat (100 gr)*

\begin{tabular}{l|cc}
\hline \multicolumn{1}{c|}{ Components } & Beef & Water buffalo meat \\
\hline Calorie (kcal) & 289 & 131 \\
Protein (gr) & 24 & 26.8 \\
Fat (gr) & 21 & 1.8 \\
Cholesterol (gr) & 90 & 61 \\
Mineral (mg) & 584 & 641.8 \\
Vitamin (mg) & 18.5 & 21 \\
\hline *(Soysal, 2009) & &
\end{tabular}

Table 3 Water buffalo numbers in some countries of the world (head)*

\begin{tabular}{l|rrrrrrr}
\hline Countries & \multicolumn{1}{|c}{1961} & \multicolumn{1}{c}{1970} & \multicolumn{1}{c}{1980} & \multicolumn{1}{c}{1990} & \multicolumn{1}{c}{2000} & \multicolumn{1}{c}{2010} & \multicolumn{1}{c}{2014} \\
\hline India & 51.207 .900 & 56.118 .000 & 66.070 .000 & 80.570 .000 & 93.831 .000 & 111.300 .000 & 110.000 .000 \\
Pakistan & 6.700 .000 & 9.345 .000 & 11.547 .000 & 17.373 .000 & 22.669 .000 & 30.800 .000 & 34.553 .000 \\
Nepal & 795.000 & 1.020 .000 & 2.500 .000 & 3.012 .570 & 3.525 .950 & 4.836 .980 & 5.178 .612 \\
Bangladesh & 500.000 & 835.000 & 475.000 & 772.000 & 890.000 & 1.349 .000 & 1.457 .000 \\
China & 8.369 .516 & 15.713 .063 & 18.439 .744 & 21.421 .967 & 22.595 .017 & 23.602 .144 & 23.345 .000 \\
Philippines & 3.452 .000 & 4.431 .500 & 2.870 .270 & 2.764 .950 & 3.024 .400 & 3.270 .400 & 2.844 .149 \\
Vietnam & 2.252 .000 & 2.270 .700 & 2.313 .000 & 2.854 .100 & 2.897 .200 & 2.913 .390 & 2.511 .900 \\
Myanmar & 1.048 .520 & 1.540 .720 & 1.901 .000 & 2.061 .000 & 2.441 .240 & 3.000 .000 & 3.422 .374 \\
Thailand & 4.963 .580 & 5.734 .500 & 5.650 .790 & 5.094 .270 & 1.711 .570 & 1.622 .650 & 1.020 .088 \\
Indonesia & 2.893 .280 & 2.885 .000 & 2.457 .000 & 3.335 .080 & 2.405 .280 & 2.005 .000 & 1.335 .200 \\
Laos DHC & 420.000 & 770.000 & 862.300 & 1.071 .760 & 1.028 .000 & 1.200 .000 & 1.153 .000 \\
Egypt & 1.501 .000 & 2.009 .000 & 2.346 .580 & 2.897 .470 & 3.379 .410 & 4.000 .000 & 3.949 .262 \\
Italy & 18.000 & 48.600 & 88.900 & 112.400 & 182.000 & 344.000 & 369.352 \\
Turkey & 1.140 .000 & 1.178 .000 & 1.040 .000 & 429.000 & 165.000 & 87.207 & 121.826 \\
Brazil & 63.000 & 118.000 & 495.000 & 1.397 .100 & 1.102 .550 & 1.184 .510 & 1.319 .478 \\
\hline World & 83.529 .592 & 102.247 .255 & 117.137 .305 & 143.854 .580 & 160.611 .854 & 191.084 .505 & 192.580 .241 \\
\hline *(FAO, 2017) & & & & & &
\end{tabular}

As seen in Table 1, the composition of water buffalo milk is superior to the milks of some other farm animals in many terms.

In terms of meat properties, water buffalo meat is one of the healthiest red meats that can be consumed by the human. It has low calorie and cholesterol. It has a dark red color because it has less intramuscular fat layer because of more pigmentation. Ingredients of beef and water buffalo meat are given in Table 2 .

\section{Water Buffalo Husbandry in the World}

Water buffalo husbandry in the world is generally most dense in the continent of Asia, which is followed by Mediterranean countries. The country with the densest breeding in American continent is Brazil. According to statistics, world's water buffalo population in the world approached 193 million head in 2014, which was 84 million head in 1961 . The country with the greatest water buffalo population figure, these figures in India went from 51 million head to 111 million head during the same period. In Mediterranean countries, Italy is leading and the population had a significant increase in this period, rising from 18 thousand head to 370 thousand head. It is believed that the contributing factor behind this increase was the brand value of mozzarella cheese, made from water buffalo milk. Turkey, Thailand and Indonesia witnessed a decrease in the 50 year period (Table 3 ). As swamp buffaloes used for their draught and bearing capacities are common in Thailand and Indonesia, mechanization in wetlands (used for paddy production) and other agricultural lands led to a decrease in the number of water buffaloes used for drought (Chantalakhana, 1996).

The worldwater buffalo population has rapidly increased after 1990, particularly in India, Pakistan and Nepal, the reasons for this can be listed as; sustainable breeding improvement studies on water buffaloes, particularly for milk production, small and medium-sized enterprises rapidly developing in suburban areas in India, decrease towards water buffalo due to the religious values attach to cattle (Borghese, 2010). Due to inflated milk prices in India and Bombay, breeders are selling water buffalo milk in street markets and this leads to an increased ratio of calf deaths. In India, 18 basic water buffalo races are being bred for milk production, while 
males are being bred for drought power and meat production (Soysal, 2006). 30-40\% of milk produced in South Asian countries is consumed as fresh milk, while the rest is consumed as dairy product (Atasever and Erdem, 2008).

Reviewing Table 3 indicates significant falls in Thailand and Brazil after the 1990's. During the last 14 years, an increase of 33 million heads has been observed in the world's water buffalo population. Looking at the distribution of water buffalo population by continents and countries, we see that Asia, the homeland of water buffalo, has the majority of the water buffalo population. Asian continent owns majority of the world water buffalo population, the figures of which are as follows; $97.7 \%$ in 1990, in $97.1 \%$ 2000, and $96.9 \%$ in 2014. Looking from this perspective, we would be on the safe side to say water buffalo breeding is a unique traditional agricultural activity in Asia. Buffaloes in Europe and Near East are classified as river type buffaloes with a focus on milk yield and their mature live weights vary between 600 and $1000 \mathrm{~kg}$ in different countries (Borghese and Mazzi, 2005).

It has been reported that artificial insemination is common practice in Italy, and the 50.000 water buffaloes measures, produced $8.4 \%$ fat and $4.6 \%$ protein with a milk yield average of $2200 \mathrm{~kg}$ in 270 days of lactation (Borghese, 2013). Dairy cattle breeding became continuously popular in Turkey until the year 2010, which led to a rapid desertion of water buffalo breeding. However, through the incentive policies of the state, a great increase in the number of water buffaloes has been observed since 2010 .

\section{Physiological, Morphological and Yield Characteristics of Water Buffaloes of Turkey}

The local race bred in Turkey and named Anatolian Water Buffalo is a farm animal with Mediterranean water buffalo origins, a sub-group of river buffaloes, and it has gained a characteristic structure unique to the conditions of Turkey. During a period lasting centuries (approximately 1500 years), Anatolian water buffalo has well-adapted to the conditions of Anatolia and Thrace and developed characteristics unique to this area (Soysal et al., 2005).

The color of water buffaloes in Turkey is generally black, and they have a backwards curved, arc-like horns. As they have fewer sweat glands than cattle, it is an absolute must-have for them to have a pond or other similar water accumulation in their home range.

Milking is generally done manually and takes place twice a day in rural areas. The milk and meat yield per water buffalo in Turkey are far behind than in the countries with developed water buffalo husbandry. In Turkey, their lactation period is 180-280 days; milk yield is $800-1100 \mathrm{~kg}$, while the mature female water buffalo is around $500 \mathrm{~kg}$ (Soysal et al., 2005; Soysal, 2006; Atasever and Erdem, 2008). The initial reproduction age of water buffaloes is 32 to 43 months, and there are 5-10 lactation periods for a water buffalo during its total lifetime (Soysal, 2006; Y1lmaz, 2013).

Anatolian water buffaloes are generally small, skinny and slight, and their figure is thick and stumpy when compared to other developed races in the world. With black udders, hooves and horns. The color of Anatolian water buffaloes ranges from dark to black. The skin is covered with long hair and they do not bear any distinguishing marks. During the breastfeeding period, young calves have black and bright hairs, which turns into a reddish color afterwards, and this goes on until they reach the age of 1-1,5. Generally there is a beard underneath the chin (Şekerden, 2001). For adult water buffaloes the height at whether of females is being expressed as $135 \mathrm{~cm}$. Young calves are breastfed generally for 3-4 months. Milking usually takes place twice a day. Carcass traits of Anatolian water buffaloes are given in Table 4. Yilmaz et al., (2017) observed the milk yield and lactation length as $763.99 \pm 18.66 \mathrm{~kg}$ and $262.63 \pm 8.37$ days in their study which on milk composition of water buffaloes in the province of Bitlis. According to the authors, if the improvement works on Anatolian water buffaloes are concentrated particularly on milk yield, there will be a noticeable increase in the yields (Soysal et al., 2007).

Table 4 Means and standard errors (SE) for certain carcass quality characteristics of male and female Anatolian Water Buffaloes*

\begin{tabular}{|c|c|c|c|c|c|}
\hline \multirow{2}{*}{ Characteristics/Units } & \multicolumn{2}{|c|}{ Male } & \multicolumn{2}{|c|}{ Female } & \multirow{2}{*}{ Sig. } \\
\hline & Mean & SE & Mean & SE & \\
\hline Hot carcass weight, kg & 325.40 & 2.65 & 288.20 & 5.99 & $* * *$ \\
\hline Carcass length, $\mathrm{cm}$ & 127.07 & 1.00 & 132.16 & 1.93 & $*$ \\
\hline Chest depth, cm & 45.37 & 0.43 & 46.26 & 0.60 & NS \\
\hline Leg length, cm & 72.62 & 1.30 & 67.87 & 0.84 & $* *$ \\
\hline Leg width, cm & 29.96 & 0.65 & 28.99 & 0.61 & NS \\
\hline Conformation score & 5.20 & 0.42 & 5.50 & 0.40 & NS \\
\hline Fatness score & 7.70 & 0.47 & 7.30 & 0.68 & NS \\
\hline Backfat thickness, cm & 19.84 & 1.69 & 19.77 & 2.06 & NS \\
\hline \multicolumn{6}{|l|}{ Fat colour parameters } \\
\hline Lightness $\left(\mathrm{L}^{*}\right)$ & 64.00 & 1.04 & 60.03 & 0.96 & $*$ \\
\hline Redness $\left(a^{*}\right)$ & 6.14 & 0.49 & 7.01 & 0.89 & NS \\
\hline Yellowness $\left(b^{*}\right)$ & 7.03 & 0.63 & 7.08 & 0.59 & NS \\
\hline $\mathrm{pHu}$ & 5.49 & 0.01 & 5.44 & 0.01 & $* * *$ \\
\hline
\end{tabular}

$*($ Soysal, 2013), NS= not significant $(\mathrm{P}>0.05)$

$* \mathrm{P}<0.05 ; * * \mathrm{P}<0.01 ; * * * \mathrm{P}<0.001$ 
Table 5 Several characteristics of Anatolian Water Buffalo raised in Turkey*

\begin{tabular}{|c|c|c|c|}
\hline Parameters & Maximum & Minimum & Sources \\
\hline Lactation Yield (kg) & $1070.5 \pm 279.9$ & $709.6 \pm 23.0$ & $\begin{array}{l}\text { Şekerden et al., (2000b) } \\
\text { Uslu, (1970b) }\end{array}$ \\
\hline Lactation Length (day) & $269.2 \pm 70.0$ & $222.0 \pm 44.2$ & $\begin{array}{l}\text { Şekerden and Tapk1, (2000a) } \\
\text { Şekerden et al., (2000b) }\end{array}$ \\
\hline Fat $(\%)$ & $8.1 \pm 0.205$ & $6.6 \pm 0.68$ & $\begin{array}{l}\text { Kök, (1996) } \\
\text { Şekerden and Tapkı, (2000a) }\end{array}$ \\
\hline Adult Body Weight & $518.6 \pm 17.2$ & $411.0 \pm 9.07$ & $\begin{array}{l}\text { İlarslan et al., (1983) } \\
\text { Uslu, (1970a) }\end{array}$ \\
\hline Calving Interval & $434.3 \pm 57.1$ & $365.2 \pm 17.5$ & $\begin{array}{l}\text { Şekerden et al., (2000a) } \\
\text { İlarslan et al., (1983) }\end{array}$ \\
\hline Age at first insemination (day) & $679.7 \pm 210.9$ & & Şekerden and Tapkı, (2000a) \\
\hline Age at first calving (day) & $1313.2 \pm 234.8$ & $964.1 \pm 3.94$ & $\begin{array}{l}\text { Şekerden et al., (2000b) } \\
\text { Ilarslan et al., (1983) }\end{array}$ \\
\hline Birth Weight (Male) & $34.3 \pm 1.20$ & $26.7 \pm 0.52$ & Uslu, (1970b) \\
\hline Birth Weight (Female) & $31.6 \pm 0.90$ & $22.1 \pm 0.48$ & $\begin{array}{l}\text { Alaçam et al., (1983) } \\
\text { Uslu, (1970b) }\end{array}$ \\
\hline Service Period & 112.45 & 70.8 & $\begin{array}{l}\text { İlarslan et al., (1983) } \\
\text { Şekerden et al., (2000b) }\end{array}$ \\
\hline Gestation Length (day) & $\begin{array}{c}326.5 \pm 5.8 \\
\text { (artificial } \\
\text { insemination) }\end{array}$ & $\begin{array}{c}317.0 \pm 51.5 \\
\text { (natural } \\
\text { insemination) }\end{array}$ & $\begin{array}{l}\text { İzgi and Asker, (1989) } \\
\text { İzgi and Asker, (1989) }\end{array}$ \\
\hline $\begin{array}{l}\text { Daily Live Weight Gain (gr) } \\
\text { (0-3 Month) }\end{array}$ & $\begin{array}{c}\text { (Male) } \\
0.483\end{array}$ & $\begin{array}{c}\text { (Female) } \\
0.456\end{array}$ & Şekerden et al., (2000c) \\
\hline $\begin{array}{l}\text { Daily Live Weight Gain (gr) } \\
\text { (3-6 Month) }\end{array}$ & $\begin{array}{c}\text { (Male) } \\
0.305\end{array}$ & $\begin{array}{c}\text { (Female) } \\
0.294\end{array}$ & Şekerden et al., (2000c) \\
\hline $\begin{array}{l}\text { Daily Live Weight Gain (gr) } \\
\text { (6-9 Month) }\end{array}$ & $\begin{array}{c}\text { (Male) } \\
0.314\end{array}$ & (Female) 0.357 & Şekerden et al., (2000c) \\
\hline $\begin{array}{l}\text { Daily Live Weight Gain (gr) } \\
\text { (9-12 Month) }\end{array}$ & (Male) 0.504 & (Female) 0.360 & Şekerden et al., (2000c) \\
\hline Fat Content of Milk & 8.1 & 6.1 & $\begin{array}{l}\text { Kök, (1996) } \\
\text { Soysal and Kök, (1997) }\end{array}$ \\
\hline Total Solid Matter of Milk & $\begin{array}{c}17.7 \\
\text { (3. Lactation) }\end{array}$ & $\begin{array}{c}15.3 \\
\text { (1. Lactation) }\end{array}$ & Şekerden et al., (2000b) \\
\hline Ash \% of Milk & 0.830 & 0.743 & $\begin{array}{l}\text { Şekerden and Tapk1, (2000a) } \\
\text { Şekerden et al., (2000b) }\end{array}$ \\
\hline Water of Milk & 82.3 & & $\begin{array}{l}\text { Kök, (1996) } \\
\text { Şekerden and Tapkı, (2000a) }\end{array}$ \\
\hline Protein $\%$ of Milk & 4.6 & 4.2 & $\begin{array}{l}\text { Soysal and Kök, (1997) } \\
\text { Kök, (1996) }\end{array}$ \\
\hline Casein $\%$ of Milk & $\begin{array}{c}3.4 \\
\text { (3. Lactation) }\end{array}$ & $\begin{array}{c}3.0 \\
\text { (1. Lactation) }\end{array}$ & Şekerden et al., (2000b) \\
\hline
\end{tabular}

*(Soysal, 2013)

Findings of studies conducted by different authors on the physiologic and morphologic traits of Anatolian water buffaloes are given in Table 5.

\section{Water Buffalo Husbandry in Turkey}

When we review the regional distribution of water buffalo population, following the numerical change in Turkey (Figure 1), The Black Sea Region, with many traditional water buffalo breeding provinces, tops the list with a share of $37.2 \%$ (43.846 heads). Black Sea region is followed by another traditional water buffalo breeder region, Marmara, with a share of $17 \%$. The third place is occupied by one of our central regions, Eastern Anatolian Region, with $15,5 \%$ and it is followed by Central
Anatolian Region with a share of $12 \%$. The shares of the remaining regions are below $10 \%$ and the water buffalo population in The Mediterranean Region in particular is highly insignificant (Şahin, 2015).

Increased demand of investing on intensive milk cattle breeding in recent years and inclination towards Holstein and Simmental cattle races, creates a disadvantage for low milk yielding water buffalo, and low precipitation levels and global climate change, in particular are among the reasons of decreasing water buffalo population levels (Aköz et al., 2017). As seen in Figure 1, water buffalo husbandry is mostly carried out in regions with high levels of precipitation and in the Black Sea, Marmara and Eastern Anatolian regions where water resources such as ponds and streams are available. 
Table 6 Top 20 provinces of Turkey for water buffalo population with milk yields (TUIK, 2017)

\begin{tabular}{|c|c|c|c|c|c|}
\hline Provinces & $\begin{array}{c}\text { Adult water } \\
\text { buffaloes (head) }\end{array}$ & $\begin{array}{c}\text { Young water } \\
\text { buffaloes (head) }\end{array}$ & $\begin{array}{c}\text { Total water } \\
\text { buffaloes (head) }\end{array}$ & $\begin{array}{l}\text { Water buffaloes } \\
\text { milked (head) }\end{array}$ & $\begin{array}{l}\text { Milk } \\
\text { (Ton) }\end{array}$ \\
\hline Samsun & 13904 & 4040 & 17944 & 8871 & 8782 \\
\hline Diyarbakır & 10805 & 2360 & 13165 & 6967 & 6619 \\
\hline İstanbul & 8935 & 2165 & 11100 & 5422 & 5823 \\
\hline Tokat & 6714 & 2380 & 9094 & 3224 & 3060 \\
\hline Bitlis & 7211 & 1127 & 8338 & 4535 & 4172 \\
\hline Muş & 5435 & 2000 & 7435 & 3138 & 3035 \\
\hline Afyonkarahisar & 4290 & 1308 & 5598 & 2370 & 2607 \\
\hline Kayseri & 4222 & 1241 & 5463 & 2255 & 2232 \\
\hline Sivas & 4008 & 917 & 4925 & 1754 & 2478 \\
\hline Amasya & 3115 & 1121 & 4236 & 1550 & 1614 \\
\hline Balıkesir & 3234 & 460 & 3694 & 2206 & 2235 \\
\hline Giresun & 2543 & 784 & 3327 & 1382 & 1355 \\
\hline Kütahya & 2453 & 726 & 3179 & 1237 & 1206 \\
\hline Düzce & 2306 & 793 & 3099 & 1013 & 945 \\
\hline Bartın & 2000 & 898 & 2898 & 1184 & 1078 \\
\hline Çorum & 2138 & 635 & 2773 & 1124 & 1093 \\
\hline Yozgat & 2092 & 511 & 2603 & 1255 & 1255 \\
\hline Kocaeli & 1629 & 455 & 2084 & 849 & 764 \\
\hline Iğdır & 1458 & 440 & 1898 & 676 & 676 \\
\hline Erzincan & 1196 & 599 & 1795 & 622 & 603 \\
\hline 70 provinces total & 110700 & 31373 & 142073 & 59804 & 63085 \\
\hline
\end{tabular}

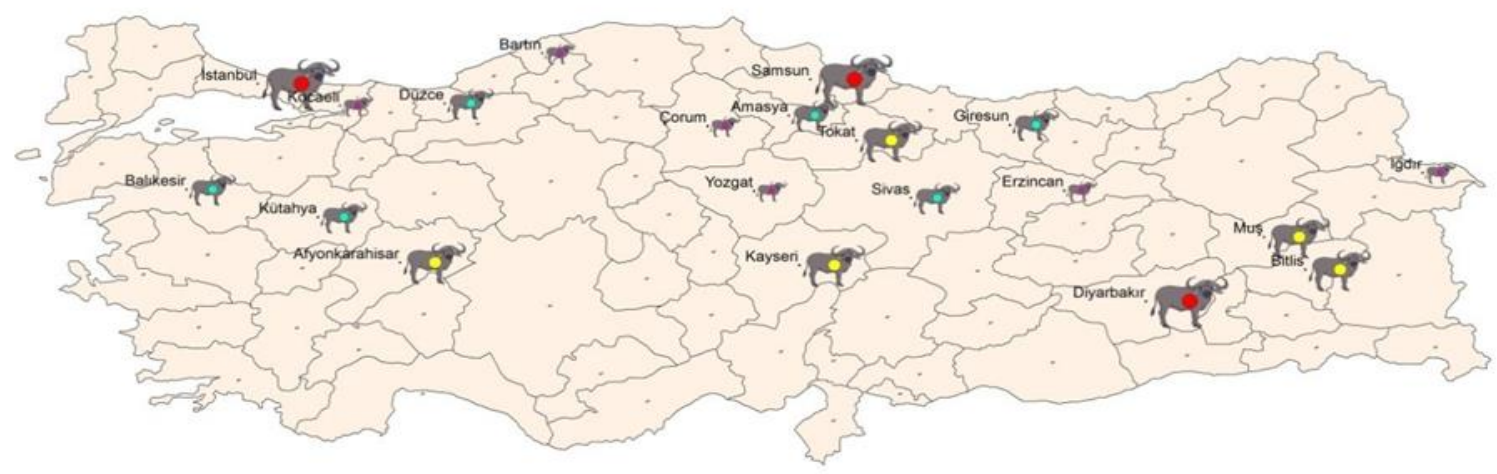

The number of water buffaloes

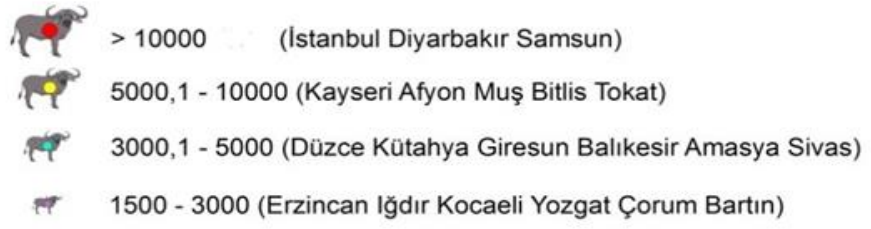

Figure 1 Distribution of the 20 provinces over 1500 heads water buffaloes in Turkey map (2017)

Water buffalo husbandry takes place in 70 out of 81 provinces in Turkey and distribution of the 20 provinces on the Turkish map with the highest water buffalo population has been given in Figure 1 and the ranking has been given in Table 6 . Looking at Table 6 , we can see that the province with the highest water buffalo population is Samsun (17.944 heads). Water buffalo is mostly done for milk production in this province and 8.782 tons of milk is being produced. Kizılirmak delta and a high level of precipitation in the region are factors for Samsun being the center of water buffalo husbandry. The increasing water buffalo husbandry in Istanbul in recent years, contributing to milk production and is meeting the water buffalo milk need of the population living in the metropolitan area.

Water buffalo milk produced in the Afyonkarahisar province is being consumed in the form Afyon cream (kaymak), which has become a traditional brand. In Kayseri, meat production comes into prominence and water buffalo is meat is particularly used when producing the famous Kayseri pastrami (pastırma). A significant achievement has been made in line with the advances in 
process meat products industry. And in Eastern and South-eastern Anatolian regions Diyarbakır, Muş and Bitlis serve as local center. In line with the recent incentives provided by the Ministry of Food, Agriculture and Livestock for water buffalo husbandry and the increased number of Water Buffalo Breeders Associations, it has been observed that the previously local-level water buffalo husbandry is now organized in many provinces and turned into commercial production.

In Diagram 1 and 2 presents the changes that occurred in Turkey in the past regarding the numbers of cattle and water buffalo. Since 1940 cattle races changed from domestic races to culture races, keeping and feeding conditions have improved and support policies have been introduced, and as a result of all these an increased yield has been achieved. Water buffalo population was over 1 million during 1970's, but following a sharp decrease until 2010, this figure fell to 85.000 water buffaloes. Thanks to the water buffalo supports since that same year the number of water buffaloes has increased to 142.000 head in 2016.

Diagram 3 presents the distribution of cow and water buffalo milk in Turkey during the past 16 years. Looking at the diagram, the increase in cattle population as well as in milk quantity can be observed, however, it can also be seen that after the year 2000 a decrease in water buffalo population was followed by a decrease in milk quantity, and following the supports introduced since year the 2010, a significant increase in milk production took place in line with the increased water buffalo population.

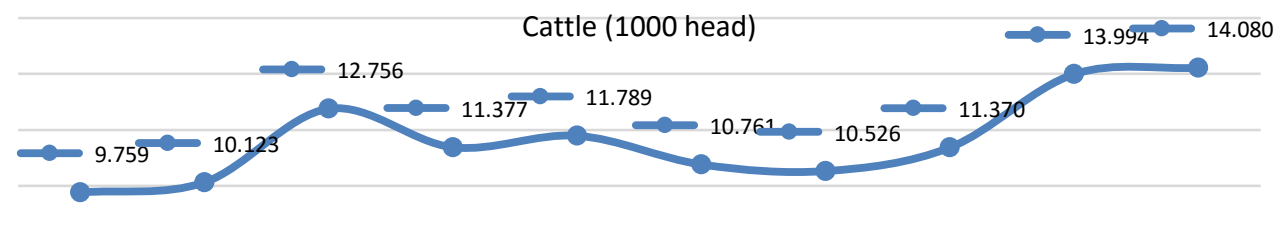

Diagram 1 Demonstration of cattle wealth of Turkey within years (1000 head) (TUIK, 2017)

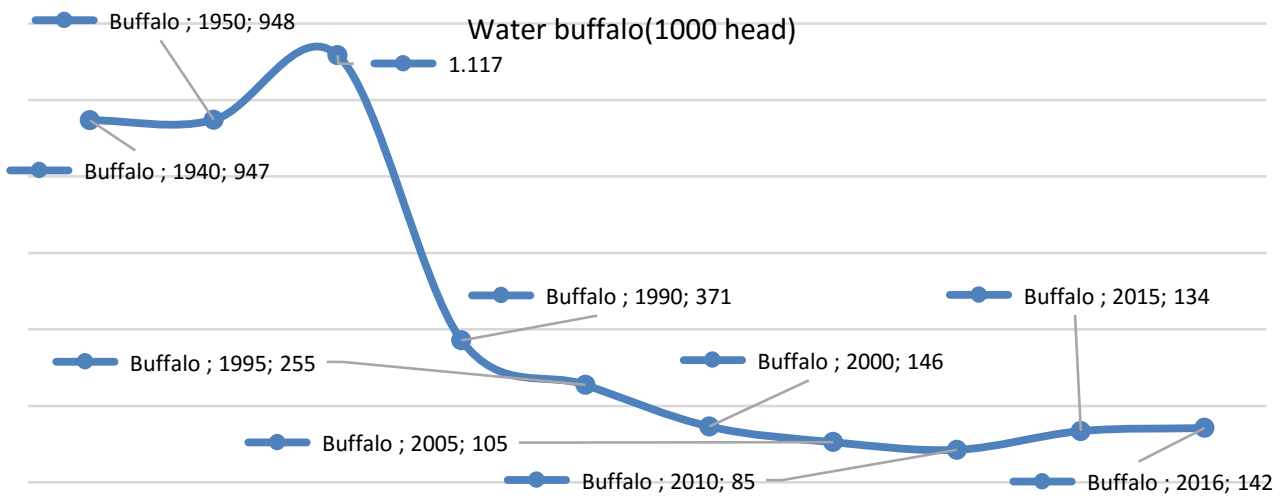

Diagram 2 The demonstration of water buffalo wealth of Turkey within years (1000 head) (TUIK, 2017)
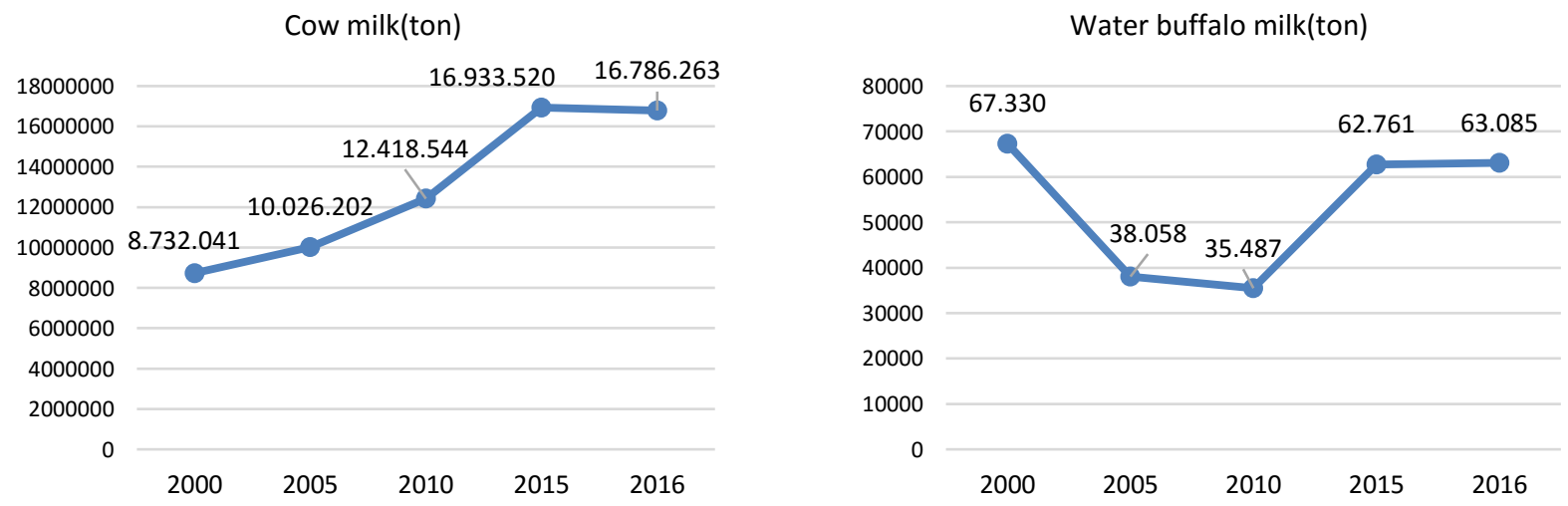

Diagram 3 Milk production from cattle and water buffalo in Turkey since 2000's (tons) (TUIK, 2017) 
As of 2017, the Central Association of Breeding Water Buffalo Breeders of Turkey has 25 provincial associations' members, and the number of enterprises affiliated to these provincial associations and the number of water buffaloes in these enterprises is presented in Table 7 (Anonymus, 2017). Table 7 indicates Diyarbakır as the province with the highest number of enterprises, and in 1225 enterprises it has 18.570 head of water buffaloes. The number water buffaloes per enterprise is 15,2 . The province with the lowest number of enterprises is Bursa, and the 28 enterprises in the province have a water buffalo population of 489 heads. Whether a member or not to the Central Association of Breeding Water Buffalo Breeders of Turkey, the average capacity of all small family enterprises is 1-5 heads, but despite this, the average figure per enterprise in Istanbul province, where water buffalo breeding generally takes place as intensive, is approximately 154 heads. The reason for this is the existence of large-scaled water buffalo husbandry enterprises, even if low in numbers, which are close to great consumption centers such as Istanbul, have no problems in marketing water buffalo milk and dairy products.

Being conducted as family husbandry with an average of 1-5 heads, generally fed with pasture based roughage in rural areas, husbandry in areas close to metropolitans is in the form of large herds with 50-100 heads, and feeding is made by hay, corn silage, clover, sugar beet pulp, barley, wheat and concentrated fodders. Artificial insemination is not a common practice in water buffaloes of Turkey, it is only applied at research institutions (Soysal, 2013).
Işık and Gül (2016), in their study conducted in Muş province to examine the economic and social structures of water buffalo breeders, have reported that most producers are doing water buffalo husbandry together with other animals, are working as a family labor force, $31 \%$ of them are marketing their dairy products by themselves, generally feed their water buffaloes in pastures and achieve an average of $954 \mathrm{~kg}$ milk during a 230 days lactation period. The keeping of the water buffaloes is generally the duty of females, breeders with low-income levels and the small amount of land are usually breeding do meet their own needs.

\section{Conclusion and Recommendations}

At the same rate of the global increase in population, the demand for food and especially for healthy food is also increasing. With the purpose of meeting the increasing demand, there is a need for low-cost, ecofriendly farming systems, along with the efforts to increase production. Water buffalo husbandry milk, dairy products and meat production must be taken into consideration as an alternative solution for food problem. Water buffaloes are animals able to make the most and convert even low-quality roughage into the meat and milk yield, has a high capacity of fodder benefiting, resistant against diseases, and when compared to culture race cattle, it does not require much care in terms of feeding. When the benefits are taken into account, there is a need to revive water buffalo husbandry, define the problems of the sector and develop new strategies.

Table 7 The number of enterprises affiliated to provincial associations of Water Buffalo Breeders' Associations of Turkey and the water buffalo populations in these enterprises*

\begin{tabular}{|c|c|c|c|}
\hline $\begin{array}{c}\text { Turkish Water Buffalo } \\
\text { Associations }\end{array}$ & Number of Enterprises & $\begin{array}{l}\text { Heads Number of Water } \\
\text { Buffalo }\end{array}$ & $\begin{array}{l}\text { Heads Number per } \\
\text { Enterprise }\end{array}$ \\
\hline Diyarbakır & 1225 & 18570 & 15.2 \\
\hline Giresun & 519 & 1217 & 2.3 \\
\hline Kütahya & 384 & 918 & 2.4 \\
\hline Bitlis & 312 & 3875 & 12.4 \\
\hline Sivas & 241 & 915 & 3.8 \\
\hline Tokat & 196 & 2980 & 15.2 \\
\hline Afyonkarahisar & 193 & 2894 & 15.0 \\
\hline Muş & 190 & 959 & 5.0 \\
\hline Samsun & 188 & 22154 & 117.8 \\
\hline Bartın & 182 & 985 & 5.4 \\
\hline Çorum & 156 & 1385 & 8.9 \\
\hline Amasya & 140 & 1148 & 8.2 \\
\hline Yozgat & 138 & 1284 & 9.3 \\
\hline Balıkesir & 130 & 1458 & 11.2 \\
\hline Düzce & 127 & 1397 & 11.0 \\
\hline Kayseri & 124 & 1370 & 11.0 \\
\hline İstanbul & 85 & 13050 & 153.5 \\
\hline Kirklareli & 63 & 850 & 13.5 \\
\hline Kocaeli & 57 & 1210 & 21.2 \\
\hline Tekirdağ & 57 & 687 & 12.1 \\
\hline Çankırı & 37 & 483 & 13.1 \\
\hline Sinop & 35 & 384 & 11.0 \\
\hline Bolu & 32 & 984 & 30.8 \\
\hline Zonguldak & 32 & 532 & 16.6 \\
\hline Bursa & 28 & 489 & 17.5 \\
\hline Total & 4871 & 82178 & 16.9 \\
\hline
\end{tabular}


Income levels in rural areas must be increased by providing water buffalo breeders in rural areas by ensuring sustainability through national supports as well as incentives and induced activities provided by local authorities. By improving animal husbandry, migration from towns to provinces will be prevented, producers will be getting the opportunity to continue their traditional water buffalo breeding methods with more modern and technical conditions. Distribution of breeder material in places suitable for water buffalo husbandry must be taken under the scope of incentive competitions, festivals and other similar activities to increase awareness.

It is necessary to protect, improve and rectify the conditions for the breeding of Anatolian water buffalo race, which has adapted to Turkey and is being bred in rural areas for many centuries. Production made under traditional conditions needs to be improved through farmer training, and planning must be made to continue with research, training and supports to make the best use of water buffalo meat-milk products. In areas suitable for water buffalo husbandry, protection must be encouraged by special incentives to increase the number of enterprises, productive applications for producer development need to be defined and in particular the young population needs to be directed towards this field. In areas with intense levels of water buffalo husbandry, new projects must be prepared to improve low productivity through raising pure races and crossbreeding, successful National Breeding Projects must be continued with improvement. Efforts must be made to help water buffalo milk and meat products, which are highly suitable for organic production, to be produced, used and marketed organically. Producers need to eliminate production and marketing related problems by becoming organized. On the other hand, water buffalo meat and milk and the superiorities, in terms of taste and health, of products made from them should be explained to consumers through media and public service ads to create demand. As incentives by Ministry of Food, Agriculture and Livestock, activities Association of breeding and studies at universities and research institutes on water buffalo husbandry and improvement increases, the number of water buffaloes has risen in recent years and it must be ensured that this becomes sustainable. Sustainability in water buffalo husbandry is also seen as an important potential for being an improving enterprise for water buffalo husbandry areas and to meet the increasing demand for animal food products.

\section{References}

Aköz M, Arik D, Kul M, Çelik B. 2017. Buffalo breeding: Buffalo breeding in Turkey from past to today. International Journal of Scientific and Technological Research www.iiste.org ISSN 2422-8702 (Online), 3(2):9-14.

Alaçam E, Kilıçoğlu Ç, Özgür H. 1983. İneklerde prostaglandinlerle çalışmalar. 1. Östrüs senkronizasyonu, Uludağ Üniversitesi Vet. Fak. Derg. 2 (1):65-72.

Anonymus. 2003. Manda Yetiştiriciliği Hakkında Genel Bilgiler Kitabı. Tarım ve Köyişleri Bakanlığı Kocatepe Tarımsal Araştırma Enstitüsü. Afyon.

Anonymus. 2017. Türkiye Damızlık Manda Yetiştiricileri Merkez Birliği verileri. http://www.dmymb.org. (Access Date: 01.06.2017).
Atasever S, Erdem H. 2008. Manda yetiștiriciliği ve Türkiye'deki geleceği. OMÜ Ziraat Fak. Derg. 23(1):59-64.

Borghese A, Mazzi M. 2005. Buffalo population and strategies in the world. Buffalo Production and Research. Reu Technical Series 67, 1-41.

Borghese A. 2010. Development and perspective of buffalo and buffalo market in Europe and Near East. https://www.researchgate.net/publication/267380581.

Borghese A. 2013. Buffalo livestock and products in Europe. Buffalo Bulletin 2013. 32 (Special Issue 1):50-74.

Chantalakhana C. 1996. Changing economies in Asia and Buffalo references production in the 21st century. In Proceedings of the Second Asian Buffalo Association Congress, edited by V.G. Momongan, et al. PSAS Foundation, Inc., College, Laguna, Philippines, 1-10.

Demirci M. Yüksel AN. Soysal Mİ. 1991. Memeden mamül maddeye süt. Hasad Yayıncılık Hayvancılık Serisi:1, 364.

El-Salam MHA, El-Shibiny S, 2011. A comprehensive review on the composition and properties of Buffalo milk. Dairy Science \& Technology, 91, 6, 663.

FAO. 2014. Food and Agricultural Organization of the United Nations. http://faostat.fao.org/site/573/default.aspx\#ancor. (Access Date: 20.06.2017)

Fisher H. 1975. The water buffalo. A physiological survey of types and uses. Animal Research and Adevelopment, 1, 118-130.

Guyton AC. 1991. Textbook of Medical Physiology. Eighth Edit. W.B. Saunders Company, Philadelphia.

Harvey D. 1963. Some aspects of the importance of Buffaloes as farm stock. Reprinted from Nutrition Abstracts and Reviews, 33:931-936.

Işık M. Gül M. 2016. Economic and social structures of Water Buffalo farming in Muş province of Turkey. Revista Brasileira de Zootecnia. On-line version ISSN 1806-9290. R. Bras. Zootec. 45(7):400-408.

İlarslan MA, Karabulut A, Aşkın N. İzgi. 1983. Yerli mandalarda vücut yapısı, döl ve süt verimi üzerine araştırmalar. Zirai Araş. Enst. Yay. No:14 Afyon.

İzgi AN, Asker R. 1989. Çeşitli çevre şartlarının mandaların doğum ağırlığı üzerine etkisi. Mandacılık Araş. Enst. Yayın No:18 Afyon.

Kök S. 1996. Marmara ve Karadeniz bölgesinin çeşitli illerindeki manda populasyonlarının kimi morfolojik ve genetik özellikleri üzerinde bir araştırma. Trakya Üniv. Fen Bilimleri Enst. Doktora Tezi.

Küçükkebapçı M, Şahin M. 2002. Dünyada ve Türkiye'de mandacılık semineri. Kocatepe Tarımsal Araştırma Enstitüsü, Afyon.

Oysun G. 1987. Süt kimyası ve biyokimyası. OMÜ Yayınları. Yayın no: 18, 194.

Sarı̈̈zkan S. 2011. Türkiye'de manda yetiştiriciliğinin önemi, Kafkas Univ. Vet. Fak. Derg. (1): 163-166.

Şahin G. 2015. Türkiye zirai hayatında manda (Bubalus bubalis) yetiştiriciliği ve manda ürünlerinin değerlendirilmesi. İstanbul Üniversitesi Edebiyat Fakültesi Coğrafya Derg. 31. ISNN 1302-7212.

Şekerden Ö, Tapkı İ. 2000a. Mustafa Kemal Üniversitesi manda sürüsü süt ve döl verim özellikleri. Atatürk Üniv. Zir. Fak. Derg.

Şekerden Ö, Kebapçı M. 2000b. Afyon Kocatepe Tarımsal Araştırma Enstitüsü Anadolu mandalarında laktasyon süt verim ve bileşiminin laktasyon dönemlerine göre değişimi. Süt ve Döl Verim Özellikleri. Atatürk Üniv. Zir. Fak. Derg.

Şekerden Ö, Kebapçı M, Kopar A. 2000c. Kocatepe Tarımsal Araştırma Enstitüsü Anadolu manda sürüsünün kan serumu Tf Tipleri, Tf tipleri için genetik yapısı ve büyüme performans1, tf tipleri ve büyüme özelliği arasındaki ilişkiler. Atatürk Üniv. Zir. Fak. Derg. 2(3):240-244. 
Şekerden Ö. 2001. Büyükbaş Hayvan Yetiştirme Kitabı (Manda Yetiştiriciliği). Temizyürek Matbaacılık Antakya-Hatay.

Soysal Mİ, S Kök. 1997. Ergin mandaların bazı vücut özelliklerine ilişkin korelasyon matrix sonuçları. T. Ü. Tekirdağ Ziraat Fak. Zootekni Bölümü, Trakya Bölgesi II. Hayvancılık Sempozyumu Kitabı.147-149.

Soysal Mİ, Kök S, Gürcan E.K. 2005. Mandalarda alyuvar potasyum polimorfizmi üzerine bir araştırma. Tekirdağ Zir. Fak. Derg. 2 (2): 189-193.

Soysal Mİ. 2006. Manda ve ürünleri üretimi. Tekirdağ Üniversitesi Ziraat Fakültesi Zootekni Bölümü, Ders Notları. Tekirdağ.

Soysal Mİ, Tuna Y.T, Gürcan E.K, Özkan E, Kök S, Castellano N, Çobanoğlu O, Barone C.M.A. 2007. Anatolian Water Buffaloes husbandry in Turkey: Preliminary results on somatic characterization, Italian Journal of Animal Science, 6:sup2, 1302-1307, DOI: 10.4081/ijas.2007.s2.1302.

Soysal Mİ. 2009. Manda ve ürünleri üretimi. Namık Kemal Üniversitesi Ziraat Fakültesi Zootekni Bölümü, Ders Notları. ISBN NO: 978-9944-5405-3-7, 237, Tekirdağ.

Soysal Mİ. 2013. Anatolian Water Buffalo husbandry in Turkey. Buffalo Bulletin. 32 (Special Issue 1): 293-309.
TUİK. 2017. Türkiye İstatistik Kurumu Hayvancılık İstatistikleri. http://www.tuik.gov.tr. (Access Date: 01.06.2017).

Uslu NT. 1970a. Afyon bölgesi mandalarının çeşitli özellikleri ve köy şartlarında süt verimleri üzerinde mukayeseli araştırmalar. (Doktora Tezi) Birlik Matbaası, Bornova.

Uslu NT. 1970b. Büyüme döneminde bulunan mandaların protein ve nişasta değeri ihtiyaçları üzerinde çalışmalar. Yem Bitkileri Deneme ve Üretme İst. Yayın No.5 Afyon.

Wanapat M, Sungchhang K. 2013. World buffalo production: Challenges in meat and milk production, and mitigation of methane emission. Buffalo Bulletin,32 (Special Issue 1):121.

Yılmaz A, Ocak E, Köse Ş. 2017. A Research on milk yield, milk composition and body weights of Anatolian Buffaloes. Indian J. Anim. Res., 51 (3) 2017: 564-569 Print ISSN:0367-6722 / Online ISSN:0976-0555.

Yılmaz S. 2013. Afyonkarahisar Yöresi Manda Yetiştiriciliği; Küçükçobanlı Köyü Örneği. Doktora tezi. Adnan Menderes Üniversitesi Fen Bilimleri Enstitüsü Zootekni Anabilim Dalı 2013-Y1-023. 